\title{
HUBUNGAN LAMA PAPARAN INHALASI ORGANICSOLVENT TERHADAP PENURUNAN PENGLIHATAN WARNA DAN SENSITIVITAS KONTRAS
}

\author{
Husnaini, Getry Sukmawati, Andrini Ariesti \\ ${ }^{1}$ Fakultas Kedokteran, Universitas Andalas, Bagian Ilmu Kesehatan Mata RSUP DR.M.Djamil Padang \\ email: husnaini zahra@ymail.com \\ ${ }^{2}$ Fakultas Kedokteran, Universitas Andalas, Bagian Ilmu Kesehatan Mata RSUP DR.M.Djamil Padang \\ email: getry_sukmawati@yahoo.com \\ ${ }^{3}$ Fakultas Kedokteran, Universitas Andalas, Bagian Ilmu Kesehatan Mata RSUP DR.M.Djamil Padang \\ email: andriniariesti@yahoo.co.id
}

Submitted : 10-04-2020, Reviewer:13-03-2020, Accepted: 13-04-2020

\begin{abstract}
Introduction: Chronic inhalation of organic solvents causes retinal toxicity such as decreased color vision and contrast sensitivity because organic solvents cause damage to photoreceptor function, changes in cortical or retinal neurotransmitter systems such as glutamate, dopamine and acetylcholine and changes in function in parvo, magno and coniocellular cells. Method: The sample of this study consisted of 45 gas station operators who were divided into 3 groups, namely those who worked 1 year-5 years, 5 years-10 years and >10 years. All subjects underwent quantitative color vision examination by calculating the value of the color confusion index (CCI) using Fansworth D15. Contrast sensitivity examination is by determining the log contrast sensitivity value using the Pelli-Robson test. Results: CCI values> 1.00 and log contrast sensitivity values $<1.65$ were found in officers who worked for $>10$ years by 12 subjects (80\%). Statistically there is a significant relationship between the duration of work with the decrease in color vision and contrast sensitivity (P Value 0,000). Conclusion: There is a significant relationship between the duration of exposure to organic solvents with a decrease in color vision and contrast sensitivity in operator officers who work $>10$ years.
\end{abstract}

Keywords: Organic solvent, color vision, contrast sensitivity, gas station

\begin{abstract}
Abstrak
Pendahuluan : Inhalasi kronis organic solvent menyebabkan toksisitas retina berupa penurunan penglihatan warna dan sensitivitas kontras karena organic solvent menyebabkan kerusakan fungsi fotoreseptor, perubahan sistem neurotransmitter kortikal atau retina seperti glutamate, dopamine dan acetylcholine serta perubahan fungsi pada sel parvo, magno dan koniocelluler. Metode: Sampel terdiri dari 45 orang petugas operator SPBU yang dibagi menjadi 3 kelompok, yaitu yang bekerja 1 tahun-5 tahun, 5 tahun-10 tahun dan >10 tahun. Semua subyek dilakukan pemeriksaan penglihatan warna dengan menghitung nilai color confusion index (CCI) menggunakan Fansworth D15. Pemeriksaan sensitivitas kontras dengan menentukan nilai log contrast sensitivity menggunakan tes Pelli-Robson. Hasil: Nilai CCI $>1,00$ dan nilai log contrast sensitivity $<1,65$ ditemukan pada petugas yang bekerja $>10$ tahun sebanyak 12 subyek $(80 \%)$. Secara statistik terdapat hubungan yang bermakna antara lama bekerja dengan penurunan penglihatan warna dan sensitivitas kontras yang ditunjukkan dengan peningkatan nilai CCI dan penurunan nilai log contrast sensitivity ( $\mathrm{P}$ Value 0,000). Kesimpulan: Terdapat hubungan yang bermakna antara lama paparan terhadap organic solvent dengan penurunan penglihatan warna dan sensitivitas kontras yang di tunjukkan dengan peningkatan nilai CCI dan penurunan nilai log contrast sensitivity pada petugas operator yang bekerja lebih dari 10 tahun.
\end{abstract}

Kata Kunci: Organic solvemt, penglihatan warna, sensitivitas kontras, SPBU 


\section{PENDAHULUAN}

\section{Latar Belakang}

Organic solvent merupakan substansi kimia yang memiliki karakteristik fisik mudah menguap dan larut lemak. Organic solvent digunakan secara luas pada dunia industri seperti perminyakan, proses pembuatan cat, lem, cairan pembersih, pewarna, plastik, tekstil, tinta, produk pertanian dan obat-obatan. . $^{1,3,4}$

Organic solvent pada industri perminyakan terdapat pada gasoline dan diesel yang terdiri dari campuran saturated dan unsaturated hydrocarbon berupa octane, nonane, benzene dan isomernya. Paparan terhadap organic solvent pada pekerja di industri perminyakan dapat melalui inhalasi atau paparan kulit. Paparan inhalasi pada petugas operator SPBU terjadi melalui uap yang dikeluarkan melalui saluran pengisian bahan bakar kemudian terhirup ke saluran pernapasan. Proses paparan ini terjadi berulang selama petugas operator tersebut mengisi tangki dari kendaraan bermotor selama shift kerja. Konsentrasi organic solvent pada breathing zone ketika melakukan pengisian bahan bakar adalah 3,2 $\mathrm{mg} / \mathrm{m}^{3}$ atau $1 \mathrm{ppm}$, namun nilai ini juga dipengaruhi oleh kecepatan angin, suhu dan kelembaban. Nilai rata-rata paparan individu terhadap organic solvent selama shift bekerja adalah $0.15 \mathrm{mg} / \mathrm{m}^{3}$ atau 0,046 ppm. $^{5,6,7,8}$

Beberapa standar dan regulasi organic solvent mengatur mengenai level paparan di tempat kerja. Peraturan Menteri Tenaga Kerja dan Transmigrasi Republik Indonesia nomor PER/13/MEN/X/2011 tentang nilai ambang batas faktor fisika dan kimia di tempat kerja yang di ukur 1 kali dalam setahun adalah $0,5 \mathrm{ppm}$ dan memiliki nilai paparan singkat yang diperkenankan sebesar 2,5 ppm. Menurut National Institute for Occupational Safety and Health (NIOSH), batas pajanan organic solvent untuk jam kerja normal 8 jam perhari atau 40 jam perminggu untuk pekerja yang berulangkali terpapar (time weighted average / TWA) adalah $0,1 \mathrm{ppm}$, untuk nilai ambang batas pajanan singkat atau short term exposure limit (STEL) sebesar 1 ppm. American Conference of Govermental Industrial Hygienists menetapkan level TWA organic solvent yang diperbolehkan $0.5 \mathrm{ppm}$, sedangkan level STEL adalah $2.5 \mathrm{ppm}$. Level TWA yang ditetapkan menurut Occupational Safety and Health Administration 0,5 ppm, sementara level STEL adalah 5 ppm. Hayat I 2013 melakukan penilaian konsentrasi organic solvent di sebuah SPBU di Ciputat, konsentrasi yang di dapatkan adalah 0,23 ppm atau $0,73 \mathrm{mg} / \mathrm{m}^{3}{ }^{3} \cdot{ }^{9,10,11}$

Paparan organic solvent dibagi berdasarkan lama paparan menjadi akut bila terjadi dalam < 14 hari, paparan intermediet bila paparan terjadi selama 15 hari sampai 1 tahun dan paparan kronis bila terjadi selama $>1$ tahun. Paparan organic solvent 63.894 $\mathrm{mg} / \mathrm{m}^{3}$ (20.000 ppm) selama 5-10 menit dapat mengakibatkan kematian, karena toksisitas akut organic solvent menyebabkan depresi sistem saraf pusat, aritmia jantung dan gagal napas. Paparan 799-9.584 $\mathrm{mg} / \mathrm{m}^{3} \quad$ (250-3.000 $\left.\mathrm{ppm}\right)$ menyebabkan pusing, nyeri kepala, vertigo, tremor, mengantuk, delirium dan kehilangan kesadaran. ${ }^{10,12,13}$

Inhalasi kronis organic solvent menyebabkan hematotoksisitas, neurotoksisitas dan karsinogenisitas. Toksisitas yang disebabkan organic solvent terjadi melalui peroksidasi lipid, disfungsi mitokondria, kegagalan transpor elektron dan produksi energi serta mengakibatkan kerusakan integritas membran sel. Salah satu kandungan yang bersifat toksik adalah benzene. Benzene merupakan senyawa hidrokarbon aromatik rantai tertutup tidak jenuh dengan rumus kimia $\mathrm{C}_{6} \mathrm{H}_{6}$. Benzene merupakan cairan tidak berwarna, mudah terbakar dengan bau yang manis. Benzene menguap ke udara sangat cepat dan sedikit larut dalam air. ${ }^{1,10,12,13}$

Aksoy dan kawan-kawan 1972 melakukan studi pada 32 orang yang 
terpapar benzene secara kronik dengan konsentrasi $150-650 \mathrm{ppm}$ selama 4 bulan hingga 15 tahun. Hasil dari pemeriksaan darah menunjukkan pansitopenia, 4 orang terdiagnosis leukemia myeloid metaplasia. ${ }^{14}$

Paparan benzene juga menimbulkan gangguan fungsi hati dan ginjal. El shakour dan kawan-kawan 2015 melakukan penelitian untuk menilai dampak benzene pada fungsi hati dan ginjal tikus, di dapatkan intoksikasi benzene menyebabkan peningkatan aktivitas enzim hati, bilirubin, peningkatan ureum dan kreatinin serum. ${ }^{15}$

Petugas operator SPBU kota Padang memiliki jam kerja yang melebihi ketetapan Peraturan Menteri Tenaga Kerja dan Transmigrasi Republik Indonesia. Peningkatan durasi kerja ini akan meningkatkan frekuensi paparan organic solvent pada petugas operator sehingga meningkatkan risiko kesehatan. Susilanintyas M dan kawan-kawan 2018 melakukan penelitian mengenai hubungan paparan benzene dengan fungsi paru pada awak mobil tangki di PT.X Semarang, di dapatkan responden dengan masa kerja yang lebih dari 5 tahun mengalami gangguan kapasitas paru sebanyak $52,9 \%{ }^{16}$

Dase T dan kawan-kawan 2013 menilai kapasitas paru pada petugas operator SPBU. Gangguan kapasitas paru paling tinggi dialami oleh responden dengan masa kerja kategori lama (>3 tahun) yakni sebanyak $75 \%$ (18 orang). Hasil uji statistik diperoleh $\mathrm{p}$ value $=0,019$ terdapat hubungan yang bermakna antara masa kerja dengan gangguan kapasitas paru yang dialami oleh operator SPBU. ${ }^{17}$

$$
\text { Paparan organic solvent }
$$
menyebabkan beberapa perubahan pada retina. Penglihatan warna dan sensitivitas kontras adalah bagian yang dipengaruhi oleh paparan organic solvent. Gangguan penglihatan warna di dapat ini sering dilaporkan mengenai blue yellow dimension. Penelitian Lee dan kawan-kawan 2007 menyatakan bahwa paparan kronik organic solvent dengan dosis rendah menyebabkan acquired dyschromatopsia pada pekerja yang sudah bekerja lebih dari 16 tahun. ${ }^{18,19,20,21}$

Bockelmann dan kawan-kawan 2005 melakukan penelitian mengenai pengaruh paparan kronik campuran organic solvent terhadap sensitivitas kontras dan penglihatan warna pada pekerja yang sudah bekerja 9 tahun, maka didapatkan penurunan sensitivitas kontras pada 28,6\% dan acquired dyschromatopsia pada $23 \%$ pekerja tersebut. $^{22}$

Semple S dan kawan-kawan 2000 melakukan penelitian untuk menilai penurunan penglihatan warna berkaitan dengan paparan organic solvent pada pekerja yang bekerja lebih dari 5 tahun. Penelitian tersebut menemukan hubungan yang signifikan antara lama paparan organic solvent dengan peningkatan colour confusion index. ${ }^{23}$

Sebuah penelitian Costa dan kawankawan 2012 menyatakan bahwa paparan kronik organic solvents memiliki efek terhadap gangguan penglihatan warna, sensitivitas kontras dan lapangan pandang pada pekerja di tempat pengisian gas yang bekerja rata-rata 9.6 tahun. Patogenesis yang menjelaskan hal ini masih belum jelas, tetapi beberapa hipotesis dari berbagai penelitian menjelaskan pengaruh langsung dari organic solvents terhadap fungsi fotoreseptor, perubahan sistem neurotransmitter kortikal atau retina seperti glutamate, dopamine dan acetylcholine serta perubahan fungsi pada sel parvo, magno dan koniocelluler yang merupakan jalur yang menghubungkan retina ke korteks visual primer melalui badan genikulatum lateral. ${ }^{24}$

Ramirez dan kawan-kawan 2013 menyatakan bahwa hydroquinone yang merupakan metabolit benzene dapat menyebabkan kerusakan oksidatif terhadap DNA, protein dan lipid di dalam sel muller pada retina manusia. ${ }^{25}$

Mekanisme kerusakan yang disebabkan oleh organic solvent dikaitkan 
dengan metabolit benzene yang terdiri dari 1,4 Benzoquinone dan 1,4 Hydroquinone. Kerusakan yang disebabkan oleh 1,4 Benzoquinone membutuhkan Nicotinamide adenine dinucleotide (NADH) dan Cuprum (II) sedangkan kerusakan yang disebabkan 1,4 Hydroquinone hanya membutuhkan Cuprum (I). Reduksi 1,4 benzoquinone yang di mediasi oleh NADH dan autooksidasi dari 1,4 hydroquinone menghasilkan semiquinone radical. Reaksi semiquinone dan NAD radikal dengan $\mathrm{O} 2$ menghasilkan $\mathrm{O} 2-$, kemudian di ubah untuk menghasilkan hydrogen peroxide $\left(\mathrm{H}_{2} \mathrm{O}_{2}\right)$. Hydrogen peroxide masuk ke lapisan retina luar melalui arteri koriokapilaris, kemudian menembus membran sel termasuk membran luar dan dalam dari mitokondria. Segmen dalam sel fotoreseptor mengandung konsentrasi tinggi mitokondria sehingga sel ini dapat menjadi target stres oksidatif. $26,27,28,29$

Pemeriksaan untuk menila
penglihatan warna paling sering menggunakan tablet berwarna atau diagram seperti pseudoisochromatic plate (Ishihara dan Hardy Rand Rittler plate) dan panel test. Ishihara test merupakan pemeriksaan diskriminasi warna yang terdiri dari sejumlah plate yang berisi dots dengan warna, ukuran dan kecerahan tertentu. Panel test merupakan pemeriksaan diskriminasi warna menggunakan farnsworth panel D15 atau farnsworth munsell 100 hue. Pemeriksaan ini lebih akurat dalam mengklasifikasi defisiensi penglihatan warna. Farnsworth panel D15 mudah digunakan, efektif dan dapat mendeteksi kelainan penglihatan warna di dapat. ${ }^{30,31,32,33}$

Pemeriksaan sensitivitas kontras sering menggunakan grating atau huruf pada level kontras yang bervariasi untuk menentukan ambang kontras fovea pasien. Tes grating yang sering digunakan adalah Arden Plates, Cambridge Grating, Vision Contrast Test System (VCTS), Functional Acuity Contrast Test (FACT) dan CSV-1000 (Vector vision). Sensitivitas kontras dapat juga diperiksa menggunakan huruf dengan kontras yang berbeda-beda seperti tes Regan, Mars dan Pelli-Robson. ${ }^{34,35,36}$

Salah satu upaya pencegahan terhadap penyakit akibat kerja pada petugas operator SPBU adalah alat pelindung diri. Alat pelindung diri dapat melindungi seseorang yang fungsinya mengisolasi sebagian atau seluruh tubuh dari potensi bahaya di tempat kerja. Salah satu alat pelindung diri adalah masker. Pacitto dan kawan kawan (2019) menyatakan bahwa masker wajah efektif menyaring partikel yang berukuran di bawah 2,5 $\mu \mathrm{m}$ (PM 2,5) dengan presentase $48 \%{ }^{37}$

\section{Rumusan Masalah}

Sumber potensial pajanan organic solvent pada petugas operator di SPBU berasal dari sumber pajanan tetap yang berasal dari penyimpanan BBM bawah tanah dan mesin pompa bahan bakar. Besarnya paparan pada petugas operator di SPBU di tentukan oleh nilai konsentrasi organic solvent, kecepatan inhalasi, frekuensi dan durasi pajanan. Semakin besar nilai tersebut, maka akan semakin besar paparan pada petugas operator SPBU. ${ }^{38}$

Berdasarkan rumusan masalah diatas, peneliti ingin menilai apakah terdapat hubungan antara lama paparan inhalasi organic solvent dengan penurunan penglihatan warna dan sensitivitas kontras pada petugas operator pengisian bahan bakar minyak di SPBU kota Padang.

\section{Tujuan Penelitian}

\section{Tujuan Umum}

Mengetahui hubungan antara lama paparan inhalasi organic solvent dengan penurunan penglihatan warna dan sensitivitas kontras pada petugas operator pengisian bahan bakar minyak di SPBU kota Padang.

\section{Tujuan Khusus}

1. Mengetahui penurunan penglihatan warna dan sensitivitas kontras menggunakan tes Farnsworth Munsell 
D15 dan Pelli-Robson pada petugas operator pengisian bahan bakar minyak yang bekerja 1 tahun sampai 5 tahun di SPBU kota Padang yang sudah beroperasi lebih dari 10 tahun.

2. Mengetahui penurunan penglihatan warna dan sensitivitas kontras menggunakan tes Farnsworth Munsell D15 dan Pelli-Robson pada petugas operator pengisian bahan bakar minyak yang bekerja 5 tahun sampai 10 tahun di SPBU kota Padang yang sudah beroperasi lebih dari 10 tahun.

3. Mengetahui penurunan penglihatan warna dan sensitivitas kontras menggunakan tes Farnsworth Munsell D15 dan Pelli-Robson pada petugas operator pengisian bahan bakar minyak yang bekerja lebih dari 10 tahun di SPBU kota Padang yang sudah beroperasi lebih dari 10 tahun.

4. Mengetahui hubungan antara lama paparan inhalasi organic solvent dengan penurunan penglihatan warna menggunakan tes Farnsworth Munsell D15 pada petugas operator pengisian bahan bakar minyak di SPBU kota Padang yang sudah beroperasi lebih dari 10 tahun.

5. Mengetahui hubungan antara lama paparan inhalasi organic solvent dengan penurunan sensitivitas kontras menggunakan tes Pelli-Robson pada petugas operator pengisian bahan bakar minyak di SPBU kota Padang yang sudah beroperasi lebih dari 10 tahun.

\section{Manfaat Penelitian}

\section{Bidang Pendidikan}

Hasil penelitian ini dapat menjadi sumber data bagi institusi, lembaga penelitian dan pihak terkait dalam pemantauan serta pengendalian polusi udara oleh organic solvent di lingkungan SPBU.

\section{Bidang Industri}

Hasil penelitian ini dapat menjadi masukan bagi pihak industri perminyakan dalam membuat kebijakan untuk pencegahan terkait paparan organic solvent di SPBU dan di harapkan pihak perusahaan dapat bertanggung jawab dalam pengobatan pada petugas SPBU yang terdeteksi mengalami penurunan penglihatan warna dan sensitivitas kontras.

\section{Bidang Klinik}

Hasil penelitian ini sebagai deteksi dini terhadap intoksikasi langsung organic solvent pada petugas operator SPBU.

\section{Bidang Masyarakat}

Manfaat di bidang masyarakat dapat berupa:

- Promotif : Memberikan edukasi kepada pekerja di SPBU untuk melakukan pemeriksaan mata secara berkala setiap 1 kali dalam 1 tahun .

- Preventif : Menggunakan alat pelindung diri berupa masker selama bekerja untuk meminimalisir paparan inhalasi dan menganjurkan kepada perusahaan untuk melakukan pemeriksaan berkala kadar organic solvent di udara 1 kali dalam setahun.

- Kuratif : kebijakan khusus dari perusahaan untuk petugas operator yang terdeteksi memiliki penurunan penglihatan warna dan sensitivitas kontras dengan cara melakukan mutasi petugas operator ke bagian yang tidak terpapar langsung dengan organic solvent dan pemeliharaan kesehatan untuk petugas operator tersebut

\section{METODE PENELITIAN}

\section{Desain Penelitian}

Penelitian ini merupakan suatu studi komparatif numerik tidak berpasangan dengan desain cross sectional.

\section{Tempat dan Waktu Penelitian}


Penelitian dilakukan di Bagian Ilmu Kesehatan Mata RSUP. DR.M.Djamil Padang pada bulan Januari 2020.

\section{Populasi dan Sampel Penelitian}

Populasi adalah semua petugas operator pengisian bahan bakar minyak di SPBU kota Padang yang berjumlah 307 orang.

Sampel adalah semua petugas operator pengisian bahan bakar minyak di SPBU kota Padang yang memenuhi kriteria pemilihan yaitu kriteria inklusi dan eksklusi.

Teknik pengambilan sampel adalah stratified random sampling. Besar sampel dihitung dengan menggunakan rumus Taro Yamane dan Slovin untuk populasi yang diketahui sebagai berikut:

$$
\begin{aligned}
& \quad \mathrm{n}=\underline{\mathrm{N}} \\
& \qquad+\mathrm{N} d^{2} \\
& \mathrm{n}=\text { Jumlah sampel } \\
& \mathrm{N}=\text { Total populasi (Jumlah seluruh } \\
& \text { anggota populasi) } \\
& d^{2}=\text { Presisi (ditetapkan } 0,25 \text { dengan } \\
& \text { tigkat kepercayaan } 95 \% \text { ) }
\end{aligned}
$$

Berdasarkan rumus diatas, maka jumlah sampel minimal adalah:

$$
\begin{aligned}
\mathrm{n} & =\underline{307} \\
& 1+307(0.25)^{2} \\
& =\underline{307} \\
& 20,18 \\
& =15,2=15
\end{aligned}
$$

Untuk masing-masing kelompok subjek dengan lama paparan organic solvent 1 tahun -5 tahun, 5 tahun - 10 tahun dan lebih dari 10 tahun adalah 15 sampel. Jumlah sampel keseluruhan adalah 45 sampel.

$$
\begin{aligned}
& \mathrm{n}=\text { Jumlah sampel } \\
& \mathrm{N}=\text { Total populasi }=307 \text { (Jumlah } \\
& \text { seluruh anggota populasi) }
\end{aligned}
$$

$d^{2}=$ Presisi (ditetapkan 0,25 dengan tigkat kepercayaan 95\%)

Peneliti akan mengundi 5 SPBU yang sudah beroperasi lebih dari 10 tahun. Peneliti mengambil 9 sampel pada masingmasing SPBU yang di undi sesuai kelompok lama kerja pada petugas operator di SPBU terpilih yang memenuhi kriteria inklusi. Setiap SPBU akan diperoleh 3 sampel yang bekerja 1 tahun sampai 5 tahun, 3 sampel bekerja 5 tahun sampai 10 tahun dan 3 sampel bekerja lebih dari 10 tahun.

\section{Kriteria inklusi dan eksklusi}

\section{Kriteria inklusi}

1. Petugas operator pengisian bahan bakar minyak di SPBU kota Padang yang tidak merokok serta bersedia ikut serta dalam penelitian dan menyanggupi mematuhi aturan pemeriksaan yang akan dilakukan.

2. Segmen anterior dan posterior normal.

\section{Kriteria eksklusi}

1. Katarak

2. Riwayat mengkonsumsi alkohol

3. Riwayat konsumsi obat-obatan atau sedang mengkonsumsi obat-obatan seperti chloroquine, ethambutol, chlorpromazine.

4. Riwayat penyakit paru.

\section{Definisi Operasional}

1. Lama paparan adalah jangka waktu dalam tahun di hitung sejak awal bekerja sebagai petugas operator pengisian bahan bakar minyak di SPBU kota Padang dengan durasi kerja 8 jam per shift.

Cara ukur : Mengukur lamanya paparan dengan menghitung lama bekerja petugas operator di SPBU.

Alat ukur : Data karyawan 
Hasil ukur: Pengelompokan berdasarkan lamanya bekerja sebagai petugas operator di SPBU

- 1 tahun-5 tahun

- 5-10 tahun

- > 10 tahun

Skala ukur : ordinal

2. Tes Farnsworth munsell D-15 merupakan tes penglihatan warna yang terdiri dari 15 cap yang menggambarkan spektrum visual yang tersusun sesuai dengan tingkatan warna yang sudah ditentukan oleh Farnsworth munsell D-15.

Cara ukur : Subjek diminta menyusun kembali 15 cap tersebut sesuai dengan spektrum warnanya, hasil ini di presentasikan sebagai color confusion index, Nilai CCI dihitung dengan membagi total color vision score dari tiap individu yang merupakan jumlah perbedaan warna menggunakan total color difference score (TCDS), kemudian dibandingkan dengan nilai reference.

Alat ukur : Fansworth D15

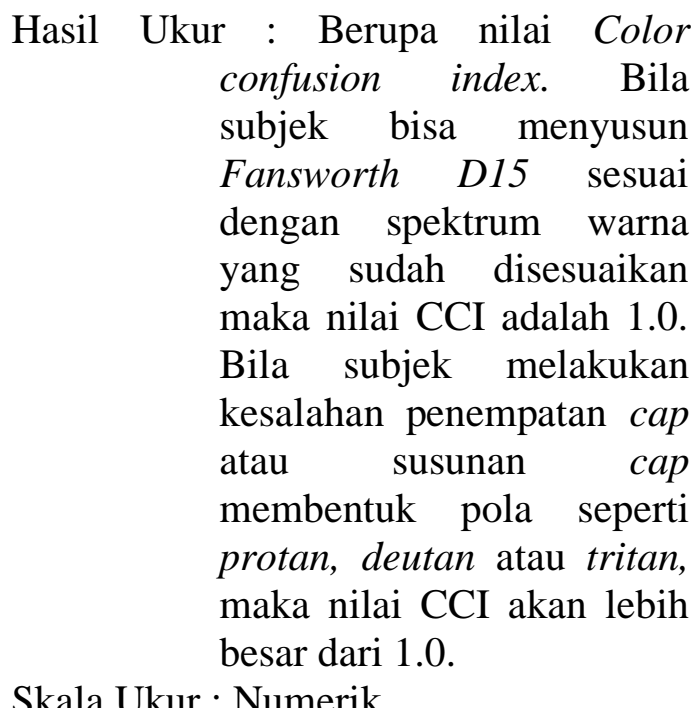

Skala Ukur : Numerik
3. Tes sensitivitas kontras Pelli-Robson merupakan penilaian sensitivitas kontras menggunakan papan Pelli-Robson.

Cara ukur : Subjek diminta untuk melihat bayangan huruf pada latar belakang putih yang dinilai dari triplet terakhir yang mampu dibaca subjek dengan minimal 2 dari 3 huruf pada triplet tersebut. Bila hanya 1 dari 3 huruf yang benar maka nilai yang diambil adalah nilai dari sensitivitas kontras di atasnya.

Alat ukur : Pelli-robson

Hasil Ukur : Nilai Log Contrast sensitivity normal $>$ 1.65. Bila nilai $<1.65$ maka terdapat penurunan sensitivitas kontras.

Skala Ukur : Numerik

\section{Hipotesis}

Semakin lama bekerja sebagai petugas operator SPBU maka semakin lama terpapar dengan organic solvent sehingga akan terjadi penurunan penglihatan warna dan sensitivitas kontras.

\section{Bahan dan Alat}

1. Snellen chart dan trial lens

2. Oftalmoskop langsung merek keeller

3. Ishihara

4. Penlight

5. Farnsworth munsell D-15

6. Papan Pelli-Robson

7. Lembar formulir hasil tes PelliRobson dan Farnsworth munsell D15.

\section{Cara dan Prosedur Kerja}

1. Pemeriksaan ini dilakukan di RS DR. M.Djamil Padang 
2. Informed consent pasien. Sebelum dilakukan pemeriksaan terhadap sampel yang memenuhi kriteria, dijelaskan terlebih dahulu tentang tujuan penelitian ini dan di minta persetujuan secara lisan menjadi subjek penelitian ini.

3. Setelah mendapat persetujuan, maka data-data subjek dan hasil pemeriksaan yang sudah dilakukan, di catat dalam status khusus penelitian.

4. Dilakukan pemeriksaan tajam penglihatan secara monokuler, mata diperiksa pada jarak 6 meter dari papan snellen. Tajam penglihatan diperiksa tanpa koreksi atau dengan koreksi, bila ditemukan kelainan pada segmen anterior maupun posterior maka subjek akan di eksklusi.

5. Lakukan pemeriksaan Ishihara untuk menyingkirkan kelainan butawarna bawaan.

6. Lakukan pemeriksaan penglihatan warna dengan farnsworth munsell D-15 monokuler, sensitivitas kontras dengan papan Pelli-Robson monokuler.

7. Dilakukan pencatatan hasil pemeriksaan pada lembar khusus penelitian.

\section{Teknik pemeriksaan penglihatan warna}

1. Subjek duduk di kursi pemeriksaan dan alat pemeriksaan farnsworth munsell D15 di atas meja di depan pasien, apabila penderita memakai kacamata maka selama pemeriksaan harus dipakai. Pemeriksaan dilakukan untuk monokuler. Salah satu mata yang tidak dilakukan pemeriksaan di tutup untuk pemeriksaan monokuler.

2. Pemeriksa menjelaskan posedur pemeriksaan farnsworth munsell D-15, kemudian pemeriksa mengacak cap tersebut, dengan salah satu cap tinggal sebagai referensi warna.

3. Subjek bertugas menyusun kembali cap tersebut sesuai susunannya selama 2
1/2- 3 menit. Pemeriksaan ini dilakukan 2 kali.

4. Hasil susunan cap dari pemeriksaan ke 2 di catat di lembar hasil fansworth D15.

5. Pemeriksa menghitung nilai CCI berdasarkan susunan cap tersebut. Nilai CCI dihitung dengan membagi total color vision score dari tiap individu yang merupakan jumlah perbedaan warna menggunakan total color difference score (TCDS) yang tercantum pada tabel dengan nilai reference.

6. Nilai CCI yang paling tinggi dimasukkan ke tabel untuk pengolahan data.

7. Bila susunan cap tersebut membentuk pola buta warna tertentu seperti protan, deutan atau tritan, maka hasil pola tersebut di catat.

\section{Teknik pemeriksaan sensitivitas kontras}

Subjek duduk di kursi dan posisi papan Pelli-Robson sejajar dengan mata pasien pada jarak 1 meter. Pemeriksa menjelaskan prosedur pemeriksaan, kemudian tentukan nilai sensitivitas kontras secara bergantian dengan cara:

- Pemeriksaan pada mata kanan dengan mata kiri di tutup (monokuler) bergantian. Subjek diminta membaca sampai triplet terakhir dengan minimal pembacaan 2 dari 3 huruf yang berbeda pada triplet tersebut. Pemeriksaan ini dilakukan 2 kali.

- Penilaian berupa nilai Log Contrast sensitivity dari pemeriksaan ke 2 di catat di lembar hasil PelliRobson.

- Nilai Log Contrast sensitivity yang paling rendah diambil dan dimasukkan ke tabel untuk pengolahan data. 


\section{Pengolahan dan analisis data}

Data deskriptif berupa variabel numerik disajikan dalam bentuk rerata standar deviasi, sedangkan variabel kategorik disajikan dalam bentuk frekuensi dan persentase. Data diolah dengan komputerisasi dan dianalisa dengan uji Kruskal-Wallis.

\section{HASIL}

\section{Karakteristik Subyek Penelitian}

Tabel 5.1 Karakteristik Subyek Penelitian

Berdasarkan Usia dan Jenis Kelamin

Tabel 5.1 menjelaskan frekuensi petugas SPBU berdasarkan usia dan jenis kelamin. Usia terbanyak adalah pada kelompok usia $>18-<30$ tahun $(57,8 \%)$ dan jenis kelamin terbanyak adalah laki-laki $(62,2 \%)$.

\section{Penglihatan Warna Pada Petugas Operator SPBU}

Tabel 5.2 Distribusi Frekuensi Nilai CCI pada Petugas Operator yang Bekerja 1-5 Tahun, 5-10 Tahun dan lebih dari 10 Tahun di SPBU Kota Padang.

\begin{tabular}{cccc}
\hline Nilai CCI & \multicolumn{2}{c}{$\mathrm{N}(\%)$} & Total \\
\cline { 1 - 3 } Lama kerja & 1,00 & $>1,00$ & \\
\cline { 1 - 3 } $1-5$ tahun & 15 & 0 & 15 \\
$5-10$ tahun & $\begin{array}{c}(100 \%) \\
15\end{array}$ & 0 & 15 \\
& $(100 \%)$ & & \\
$>10$ tahun & $3(20 \%)$ & 12 & 15 \\
\hline Total & 33 & $(80 \%)$ & \\
\hline
\end{tabular}

Pada tabel 5.2 dapat dilihat bahwa 15 subyek (100\%) petugas operator SPBU yang bekerja selama 1- 5 tahun memiliki penglihatan warna normal dengan nilai CCI 1,00. Lima belas subyek $(100 \%)$ petugas operator SPBU yang bekerja selama 5-10 tahun memiliki penglihatan warna normal dengan nilai CCI 1,00. Tiga subyek (20\%) petugas operator SPBU yang bekerja lebih dari 10 tahun memiliki penglihatan warna normal dengan nilai CCI 1,00, sedangkan 12 subyek $(80 \%)$ petugas operator SPBU yang bekerja lebih dari 10 tahun memiliki penglihatan warna dengan nilai $\mathrm{CCI}>1,00$. Nilai CCI yang paling tinggi pada kelompok ini 1,29 yang ditemukan pada 1 subyek $(9,6 \%)$.

\section{Sensitivitas Kontras Pada Petugas Operator SPBU}

Tabel 5.3 Distribusi Frekuensi Nilai Log Contrast Sensitivity pada Petugas Operator Log Contrast Sensitivity yang Bekerja 1-5 Tahun, 5- 10 Tahun dan lebih dari 10 Tahun di SPBU Kota

\begin{tabular}{|c|c|c|c|}
\hline \multirow{2}{*}{$\begin{array}{l}\text { Karakteristik } \\
\text { pasien }\end{array}$} & \multicolumn{3}{|c|}{ Frekuensi } \\
\hline & \multicolumn{2}{|c|}{$\mathrm{N}$} & $\%$ \\
\hline \multicolumn{4}{|l|}{ Usia (tahun) } \\
\hline$>18-<30$ & \multicolumn{2}{|c|}{26} & 57,8 \\
\hline$>30-<40$ & \multicolumn{2}{|c|}{10} & 22,2 \\
\hline$>40$ & \multicolumn{2}{|c|}{9} & 20 \\
\hline Jumlah & \multicolumn{2}{|c|}{45} & 100 \\
\hline \multicolumn{4}{|l|}{ Jenis Kelamin } \\
\hline Laki-laki & \multicolumn{2}{|c|}{28} & 62,2 \\
\hline Perempuan & \multicolumn{2}{|c|}{17} & 37,8 \\
\hline Jumlah & \multicolumn{2}{|c|}{45} & 100 \\
\hline \multicolumn{4}{|l|}{ Padang } \\
\hline ilai log contrast & \multicolumn{2}{|c|}{$\mathrm{N}(\%)$} & Total \\
\hline ama kerja & $>1.65$ & $<1,65$ & \\
\hline $1-5$ tahun & $\begin{array}{c}15 \\
(100 \%)\end{array}$ & 0 & 15 \\
\hline 5-10 tahun & $\begin{array}{c}15 \\
(100 \%)\end{array}$ & 0 & 15 \\
\hline$>10$ tahun & $3(20 \%)$ & $\begin{array}{c}12 \\
(80 \%)\end{array}$ & 15 \\
\hline Total & 33 & 12 & 45 \\
\hline
\end{tabular}

Pada tabel 5.3 dapat dilihat bahwa sebanyak 15 subyek (100\%) petugas operator SPBU yang bekerja 1-5 tahun yang dilakukan pemeriksaan Pelli-robson memiliki nilai log contrast sensitivity yang normal yaitu 1,65. Lima belas subyek $(100 \%)$ petugas operator SPBU yang bekerja 5-10 tahun yang dilakukan pemeriksaan Pelli-robson memiliki nilai Log Contrast sensitivity yang normal yaitu 1,65 . Tiga subyek $(20 \%)$ petugas operator SPBU yang bekerja lebih dari 10 tahun yang 
dilakukan pemeriksaan Pelli-robson memiliki nilai log contrast sensitivity yang normal yaitu >1,65. Dua belas subyek $(80 \%)$ petugas operator SPBU yang bekerja lebih dari 10 tahun memiliki nilai $\log$ contrast sensitivity $<1,65$. Nilai log contrast sensitivity paling rendah ditemukan pada 1 subyek $(9,6 \%)$ yaitu 1,35 .

Lama Bekerja dan Penglihatan Warna Pada Petugas Operator SPBU

Tabel 5.4 Hubungan Lama Bekerja dan Nilai CCI pada Petugas Operator SPBU di Kota Padang

\begin{tabular}{cccc}
\hline $\begin{array}{c}\text { Lama } \\
\text { Bekerja }\end{array}$ & $\mathrm{N}$ & $\begin{array}{c}\text { Color Confusion } \\
\text { Index } \\
\text { Rerata } \pm \mathrm{SD}\end{array}$ & $\begin{array}{c}\mathrm{P} \\
\text { value }\end{array}$ \\
\hline $\begin{array}{c}1-5 \\
\text { tahun }\end{array}$ & 15 & $1,00 \pm 0,000$ & 0,000 \\
$\begin{array}{c}5-10 \\
\text { tahun } \\
>10\end{array}$ & 15 & $1,00 \pm 0,000$ & \\
$\begin{array}{c}\text { tahun } \\
\text { tahun }\end{array}$ & 15 & $1,10 \pm 0,076$ & \\
\hline
\end{tabular}

Total 45

Uji Kruskal-Wallis

Pada tabel 5.4 dapat dilihat bahwa semakin lama bekerja, maka semakin tinggi nilai rerata CCI yang didapat. Subyek yang bekerja 1 tahun sampai 5 tahun dan subyek yang bekerja 5 tahun sampai 10 tahun memiliki nilai rerata CCI yang masih dalam batas normal yaitu 1,00. Subyek yang bekerja lebih dari 10 tahun memiliki nilai rerata CCI yang tinggi yaitu 1,10 .

Uji yang dilakukan adalah one way ANOVA, namun karena data tidak terdistribusi normal, sehingga analisa dilakukan dengan uji nonparametrik Kruskal-Wallis. Pada uji Kruskal -Wallis di dapatkan ada hubungan bermakna secara statistik antara lama bekerja dengan penurunan penglihatan warna yang ditunjukkan dengan peningkatan nilai CCI $(P$ Value 0,000).

Lama Bekerja dan Sensitivitas Kontras Pada Petugas Operator SPBU
Tabel 5.5 Hubungan Lama Bekerja dan Nilai Log Contrast sensitivity pada Petugas Operator SPBU di Kota Padang

\begin{tabular}{cccc}
\hline $\begin{array}{c}\text { Lama } \\
\text { Bekerja }\end{array}$ & $\mathrm{N}$ & $\begin{array}{c}\text { Log Contrast } \\
\text { sensitivity } \\
\text { Rerata } \pm \mathrm{SD}\end{array}$ & $\mathrm{P}$ value \\
\hline $\begin{array}{c}1-5 \\
\text { tahun } \\
5-10\end{array}$ & 15 & $1,66 \pm 0,038$ & 0,000 \\
$\begin{array}{c}\text { tahun } \\
>10\end{array}$ & 15 & $1,65 \pm 0,000$ & \\
tahun & 15 & $1,51 \pm 0,089$ & \\
\hline
\end{tabular}

Total 45

Pada tabel 5.5 dapat dilihat bahwa semakin lama bekerja sebagai petugas operator SPBU, semakin rendah nilai rerata log contrast sensitivity yang di dapat. Subyek yang bekerja lebih dari 10 tahun memiliki nilai rerata log contrast sensitivity yang paling rendah 1,51, sedangkan subyek yang bekerja 5 tahun sampai 10 tahun memiliki nilai rerata log contrast sensitivity 1,65 . Subyek yang bekerja 1 tahun sampai 5 tahun memiliki nilai rerata log contrast sensitivity paling tinggi yaitu 1,66. Pada penelitian ini tidak dapat dilakukan uji One Way ANOVA karena sebaran data tidak normal, sehingga dilakukan uji KruskalWallis. Berdasarkan uji Kruskal-Wallis di dapatkan hubungan bermakna antara lama bekerja sebagai petugas operator SPBU dengan penurunan sensitivitas kontras $(P$ value 0,000 ).

Pada penelitian ini juga dilakukan uji Mann-Whitney untuk melihat kelompok yang memiliki perbedaan yang signifikan.

Tabel 5.6 Hubungan Masing-masing Kelompok Lama Bekerja dengan nilai Color Confusion Index pada Petugas Operator SPBU di Kota Padang

\begin{tabular}{cccc}
\hline $\begin{array}{c}\text { Lama } \\
\text { Bekerja }\end{array}$ & $\mathrm{N}$ & $\begin{array}{c}\text { Color } \\
\text { Confusion } \\
\text { Index } \\
\text { Rerata } \pm \mathrm{SD}\end{array}$ & $\mathrm{P}$ value \\
\hline $\begin{array}{c}1-5 \\
\text { tahun }\end{array}$ & 15 & $1,00 \pm 0,000$ & 1,000 \\
5-10 tahun & 15 & $1,00 \pm 0,000$ & \\
\hline
\end{tabular}




\begin{tabular}{cccc}
\hline $5-10$ tahun & 15 & $1,00 \pm 0,000$ & 0,000 \\
$>10$ tahun & 15 & $1,10 \pm 0,076$ & \\
\hline $1-5$ tahun & 15 & $1,00 \pm 0,000$ & 0,000 \\
$>10$ tahun & 15 & $1,10 \pm 0,076$ & \\
\hline$\bullet$ & Uji Mann-Whitney \\
\end{tabular}
nilai CCI yang bermakna secara statistik antara lama bekerja 5-10 tahun dengan lama bekerja > 10 tahun $(\mathrm{P}$ value 0,000$)$ dan lama bekerja 1- 5 tahun dengan lama bekerja $>10$ tahun ( $\mathrm{P}$ value 0,000), sedangkan lama bekerja 1- 5 tahun dengan lama bekerja 5-10 tahun tidak bermakna secara statistik (P value 1,000).

Tabel 5.7 Hubungan Masing-masing Kelompok Lama Bekerja dengan Nilai Log Contrast sensitivity pada Petugas Operator SPBU di Kota Padang

\begin{tabular}{|c|c|c|c|}
\hline $\begin{array}{c}\text { Lama } \\
\text { Bekerja }\end{array}$ & $\mathrm{N}$ & $\begin{array}{l}\text { Log Contrast } \\
\text { sensitivity } \\
\text { Rerata } \pm \text { SD }\end{array}$ & $\begin{array}{c}\mathrm{P} \\
\text { value }\end{array}$ \\
\hline $\begin{array}{l}1-5 \\
\text { tahun }\end{array}$ & 15 & $1,66 \pm 0,038$ & 0,317 \\
\hline 5-10 tahun & 15 & $1,65 \pm 0,000$ & \\
\hline 5-10 tahun & 15 & $1,65 \pm 0,000$ & 0,000 \\
\hline$>10$ tahun & 15 & $1,51 \pm 0,089$ & \\
\hline 1-5 tahun & 15 & $1,66 \pm 0,038$ & 0,000 \\
\hline$>10$ tahun & 15 & $1,51 \pm 0,089$ & \\
\hline \multirow{4}{*}{\multicolumn{4}{|c|}{$\begin{array}{l}\text { - Uji Mann-Whitney } \\
\text { Pada tabel } 5.7 \text { didapatkan rerata nilai } \\
\text { Log Contrast sensitivity yang bermakna } \\
\text { secara statistik antara lama bekerja 5-10 } \\
\text { tahun dengan > } 10 \text { tahun (P value } 0,000 \text { ) } \\
\text { dan lama bekerja } 1-5 \text { tahun dengan }>10 \\
\text { tahun (P value } 0,000) \text {, sedangkan lama } \\
\text { bekerja 1-5 tahun dengan 5-10 tahun tidak } \\
\text { bermakna secara statistik (P value 0,317). } \\
\text { Tabel 5.8 Hubungan Nilai CCI dengan Nilai } \\
\text { Log Contrast Sensitivity pada } \\
\text { Petugas Operator SPBU di Kota } \\
\text { Padang }\end{array}$}} \\
\hline & & & \\
\hline & & & \\
\hline & & & \\
\hline & & \multicolumn{2}{|c|}{$\begin{array}{c}\text { Nilai Log Contrast } \\
\text { Sensitivity } \\
\end{array}$} \\
\hline \multirow[t]{3}{*}{ Nilai CCI } & & \multicolumn{2}{|c|}{$r=-0.780$} \\
\hline & & \multicolumn{2}{|c|}{$\mathrm{P}=0,001$} \\
\hline & & \multicolumn{2}{|c|}{$\mathrm{n}=15$} \\
\hline
\end{tabular}

- Uji korelasi Spearman
Korelasi antara nilai CCI dengan nilai $\log$ contrast sensitivity dapat dilihat pada tabel 5.8, hasil koefisien korelasi nya -0.780 dengan signifikansi 0,001 . Berdasarkan hasil tersebut, nilai signifikansi 0,001 $(<0,05)$ menunjukkan ada hubungan yang signifikan antara peningkatan nilai CCI dengan penurunan nilai log contrast sensitivity. Angka koefisien korelasi -0.780 menunjukkan bahwa kekuatan korelasi adalah 0.780 atau korelasi kuat, nilai negatif menunjukkan hubungan yang bersifat tidak searah. Jika nilai CCI meningkat, maka nilai log contrast sensitivity menurun.

\section{PEMBAHASAN}

\section{Karakteristik Subyek Penelitian}

Pada penelitian ini terlihat bahwa usia terbanyak adalah pada kelompok usia $>18$ $<30$ tahun $(57,8 \%)$ dan jenis kelamin terbanyak adalah laki-laki $(62,2 \%)$. Hal ini sesuai dengan penelitian yang di lakukan oleh Dase dan kawan kawan (2013), pada penelitian tersebut didapatkan responden yang berumur muda (<30 Tahun) lebih banyak yaitu $52 \%$ (24 orang) dibanding dengan yang berumur tua ( $\geq 30$ Tahun) yaitu sebanyak $48 \%$ (22 orang). ${ }^{17}$ Pada penelitian Hayat I (2012), di dapatkan umur rata-rata petugas operator SPBU adalah 24,5 tahun, umur minimal adalah 18 tahun, sedangkan umur maksimal adalah 54 tahun. ${ }^{9}$ Mahendra (2014) menyatakan bahwa usia tenaga kerja sangat menentukan produktivitas tenaga kerja. Tenaga kerja yang lebih tua memiliki tenaga fisik yang lemah dan terbatas, sebaliknya tenaga kerja yang berusia muda lebih memiliki fisik yang kuat. ${ }^{39}$ Usia dan jenis kelamin juga mempengaruhi toksokinetik dari organic solvent. ${ }^{40}$

\section{Penglihatan Warna Pada Petugas Operator SPBU}

Distribusi frekuensi penglihatan warna petugas operator SPBU di dapatkan 15 subyek (100\%) memiliki penglihatan warna normal dengan nilai CCI 1,00 pada petugas operator yang bekerja 1-5 tahun. Subyek yang bekerja 5 tahun sampai 10 tahun di SPBU juga memiliki nilai CCI normal yaitu 1,00. Pada subyek yang bekerja $>10$ tahun menunjukkan hasil nilai 
CCI yang normal yaitu 1,00 sebanyak 3 subyek (20\%), sedangkan $12(80 \%)$ subyek memiliki nilai CCI lebih dari 1,00. Dua belas subyek yang memiliki nilai CCI lebih dari 1,00 sudah bekerja lebih dari 13 tahun. Mereka bekerja 8 jam per hari dengan jadwal libur selama 2 hari dalam sebulan. Subyek tersebut tidak pernah menggunakan masker selama bekerja karena setiap pekerja diwajibkan melayani dengan prinsip senyum, salam dan sapa. Subyek tersebut setiap harinya terpapar dengan organic solvent di lingkungan kerja dengan konsentrasi yang tidak diketahui, karena di SPBU tersebut tidak pernah dilakukan pemeriksaan konsentrasi organic solvent di udara. Paparan kronik tanpa menggunakan alat pelindung diri tersebut di duga menyebabkan terjadinya penurunan penglihatan warna pada 12 subyek tersebut. Penurunan penglihatan warna terlihat dari peningkatan Nilai CCI yang lebih dari 1,00.

Penelitian Pots dan kawan-kawan (1995) yang dilakukan pada tikus ditemukan bahwa akumulasi metabolit pada retina menyebabkan degenerasi dari outer nuclear layer dan lapisan sel ganglion. ${ }^{41}$

Hasil penelitian ini sama dengan yang ditemukan pada penelitian Costa dan kawan-kawan (2012) yang menilai CCI pada petugas operator SPBU yang terpapar organic solvent yang sudah bekerja rata-rata 9 tahun. Pada petugas tersebut didapatkan nilai rerata CCI $1.48 .^{24}$

Hasil penelitian Gong dan kawankawan (2003) menunjukkan hasil yang sama dengan penelitian ini. Penelitian Gong membandingkan penglihatan warna kelompok yang terpapar dengan organic solvent selama 10 tahun dan kelompok kontrol. Pada kelompok yang terpapar di dapatkan nilai CCI yang lebih tinggi yaitu $1.44 .^{3}$

\section{Sensitivitas Kontras Pada Petugas Operator SPBU}

Pemeriksaan sensitivitas kontras berguna untuk skrining penyakit okuler, diagnosis penyakit okuler dan monitoring fungsi visual. Sensitivitas kontras dipengaruhi oleh berbagai kondisi fisiologis dan patologis pada mata. Berbagai faktor dapat mempengaruhi fungsi sensitivitas kontras yang normal meliputi adaptasi terhadap luminansi latar belakang, besarnya stimulus, lapangan pandang, ukuran pupil, orientasi stimulus dan berbagai faktor optik lainnya. ${ }^{42,43}$

Distribusi frekuensi pemeriksaan sensitivitas kontras pada petugas operator yang bekerja 1-5 tahun di SPBU kota padang di dapatkan sebanyak 15 subyek (100\%) yang dilakukan pemeriksaan Pellirobson memiliki nilai log contrast sensitivity yang normal yaitu 1,65. Distribusi frekuensi hasil pemeriksaan sensitivitas kontras pada petugas operator yang bekerja 5-10 tahun di SPBU kota padang di dapatkan sebanyak 15 subyek (100\%) memiliki nilai log contrast sensitivity normal yaitu 1,65. Penurunan nilai log contrast sensitivity terlihat pada petugas operator yang bekerja lebih dari 10 tahun, sebanyak 12 subyek (80\%) memiliki nilai log contrast sensitivity yang tidak normal yaitu 1,50. Nilai log contrast sensitivity paling rendah adalah 1,35, sedangkan 3 subyek (20\%) memiliki nilai log contrast sensitivity normal yaitu 1,65. Dua belas subyek yang mengalami penurunan nilai log contrast sensitivity merupakan subyek yang sama dengan subyek yang juga mengalami penurunan penglihatan warna, hal ini terjadi karena paparan kronik organic solvent pada petugas tersebut tanpa menggunakan alat pelindung diri. Tiga subyek yang bekerja lebih dari 10 tahun namun memiliki nilai log contrast sensitivity normal karena subyek tersebut selalu menggunakan masker selama pengisian BBM, sehingga mencegah paparan langsung organic solvent sehingga tidak terjadi reaksi toksisitas pada retina. Hasil penelitian ini sama dengan penelitian Costa dan kawan-kawan (2012) yang menemukan penurunan sensitivitas kontras yang signifikan pada petugas yang terpapar dengan organic solvent dengan rata-rata bekerja 9 tahun. $^{24}$ Lacerda dan kawankawan (2012) juga melakukan penelitian 
untuk membandingkan sensitivitas kontras pada pekerja yang terpapar organic solvent dengan kelompok kontrol, didapatkan nilai sensitivitas kontras yang lebih rendah pada kelompok yang terpapar pada spatial frequnecies 20 dan 30 cycle per degree. ${ }^{44}$

Gong dan kawan-kawan (2003) membandingkan nilai sensitivitas kontras antara grup yang terpapar dengan organic solvent selama 10 tahun dan grup kontrol, di dapatkan bahwa nilai sensitivitas kontras pada grup yang terpapar organic solvent lebih rendah dibandingkan grup kontrol pada spatial frequnecies 20 dan 30 cycle per degree. Pada penelitian tersebut dijelaskan bahwa penurunan sensitivitas kontras tersebut terjadi karena kerusakan pada jalur neuro-optik yang menyebabkan gangguan pada spatial frequencies tertentu dan menyebabkan penurunan sensitivitas kontras. $^{3}$

Hasil yang sama juga ditunjukkan pada penelitian Boeckelmann dan kawankawan (2003) mengenai sensitivitas kontras pada pekerja printer yang terpapar organic solvent selama 9 tahun. Hasil yang di dapatkan ditemukan abnormalitas sensitivitas kontras pada 6 dari 16 subyek. Abnormalitas sensitivitas kontras pada spatial frequencies dari 3, 6 dan 12 cycle per degree yang signifikan secara statistik. Penurunan sensitivitas kontras pada frekuensi spasial intermediet menunjukkan bahwa terjadi perubahan neural yang disebabkan oleh paparan terhadap organic solvent. $^{22}$

\section{Lama Bekerja dan Penglihatan Warna Pada Petugas Operator SPBU}

Salah satu faktor yang menyebabkan penurunan penglihatan warna adalah faktor lingkungan seperti paparan terhadap substansi kimia atau mengkonsumsi obatobatan yang bersifat toksik. Penurunan penglihatan warna merupakan manifestasi awal dari paparan terhadap substansi toksik, hal ini dapat bersifat subklinis tetapi dapat juga menunjukkan gejala dengan derajat severitas yang berbeda, tergantung lama paparan terhadap substansi toksik tersebut. ${ }^{20}$
Pada tabel 5.4 terlihat bahwa semakin lama bekerja, maka semakin tinggi nilai rerata CCI yang didapat, hal ini menunjukkan terjadi penurunan penglihatan warna. Subyek yang bekerja 1 tahun sampai 5 tahun dan subyek yang bekerja 5 tahun sampai 10 tahun memiliki nilai rerata CCI 1,00 . Penurunan penglihatan warna terlihat pada subyek yang bekerja lebih dari 10 tahun dengan nilai rerata CCI yang tinggi yaitu 1,10 .

Pada penelitian ini dilakukan uji Kruskal -Wallis. Dengan uji ini di temukan hubungan bermakna secara statistik antara lama bekerja dengan penurunan penglihatan warna yang ditunjukkan dengan peningkatan nilai CCI ( $P$ Value 0,000$)$. Pada uji Mann-Whitney juga di dapatkan hasil yang bermakna secara statistik antara kelompok yang bekerja 1-5 tahun dengan > 10 tahun dan 1-5 tahun dengan $>10$ tahun dengan nilai $P$ value 0,000 .

Hasil penelitian ini sama dengan yang ditemukan pada penelitian Costa dan kawan-kawan yang menyatakan bahwa terdapat korelasi yang signifikan antara lama bekerja dan nilai CCI pada pekerja yang terpapar dengan organic solvent, rerata nilai CCI pada pekerja tersebut adalah 1.48. Paparan yang lama terhadap organic solvent pada petugas operator SPBU menyebabkan gangguan fungsi visual dalam berbagai aspek, salah satunya pada penglihatan warna. Paparan terhadap organic solvent menyebabkan perubahan pada fungsi sel parvo, magno dan koniocelluler. Hal ini yang diduga memiliki hubungan yang signifikan antara lama bekerja dan gangguan penglihatan warna. ${ }^{24}$

Semple dan kawan-kawan (2000) melakukan penelitian untuk menilai kehilangan penglihatan warna berkaitan dengan paparan organic solvent. Hasil penelitian ini menunjukkan terdapat hubungan antara penurunan penglihatan warna dan lama paparan organic solvent $(\mathrm{P}=0,0029){ }^{23}$

$$
\text { Beckman (2016) melakukan }
$$
pemeriksaan penglihatan warna pada pekerja Automotive Mechanics, didapatkan 
prevalensi gangguan penglihatan warna $22,6 \%$ dan $16,7 \%$ mengalami gangguan penglihatan warna biru-kuning. Pada penelitian tersebut di simpulkan bahwa terdapat hubungan antara paparan organic solvent dan gangguan penglihatan warna biru-kuning. Pada penelitian ini dari semua subyek yang mengalami penurunan penglihatan warna, di dapatkan gangguan penglihatan warna biru-kuning, tetapi subyek ini tidak menunjukkan suatu pola tertentu. ${ }^{45}$

Hasil penelitian ini berbeda dengan penelitian yang dilakukan Ihrig dan kawankawan (2003) mengenai paparan jangka panjang organic solvent pada pekerja 140 laki-laki yang bekerja di painters. Hasil yang di dapatkan tidak terdapat hubungan yang signifikan antara nilai CCI dan paparan kronik organic solvent. ${ }^{46}$

\section{Lama Bekerja dan Sensitivitas Kontras Pada Petugas Operator SPBU}

Semakin lama bekerja sebagai petugas operator SPBU, semakin rendah nilai rerata log contrast sensitivity yang di dapat seperti yang terlihat pada tabel 5.5, subyek yang bekerja lebih dari 10 tahun memiliki nilai rerata log contrast sensitivity yang paling rendah 1,51 , sedangkan subyek yang bekerja 5 tahun sampai 10 tahun memiliki nilai rerata log contrast sensitivity 1,65 . Subyek yang bekerja 1 tahun sampai 5 tahun memiliki nilai Log Contrast sensitivity paling tinggi yaitu 1,66. Uji Kruskal-Wallis yang dilakukan pada penelitian ini menunjukkan hubungan bermakna antara lama bekerja sebagai petugas operator SPBU dengan penurunan sensitivitas kontras ( $P$ value 0,000). Pada uji MannWhitney juga di dapatkan hasil yang bermakna secara statistik pada kelompok yang bekerja 1-5 tahun dengan > 10 tahun dan 1-5 tahun dengan $>10$ tahun dengan nilai $P$ value 0,000 .

Hasil yang sama juga ditemukan pada penelitian Allam dan kawan-kawan (2017) mengenai sensitivitas kontras pada pekerja yang terpapar dengan organic solvent lebih dari 10 tahun. Pada penelitian tersebut didapatkan penurunan sensitivitas kontras pada kelompok yang terpapar dan terdapat hubungan yang signifikan antara sensitivitas kontras dan lama bekerja dengan nilai $\mathrm{P}$ $<0,001$. Penyebab dari penurunan sensitivitas kontras adalah karena kerusakan sel ganglion retina. Sel ganglion retina tidak hanya penting untuk tajam penglihatan, tetapi juga berfungsi untuk penglihatan warna dan sensitivitas kontras. Penglihatan warna dan sensitivitas kontras lebih dahulu di pengaruhi dari tajam penglihatan. ${ }^{47}$

Hasil yang sama juga di nyatakan pada penelitian Indhushree dan kawankawan (2017), pemeriksaan sensitivitas kontras dilakukan pada pekerja yang ratarata bekerja 15 tahun, dari pemeriksaan tersebut di dapatkan penurunan sensitivitas kontras pada spatial frequencies 12 cycle per degree. ${ }^{48}$

Fiedler dan kawan-kawan (2018) meneliti mengenai paparan organic solvent pada pekerja di pabrik cat, subyek yang terpapar dengan organic solvent selama lebih dari 10 tahun menunjukkan penurunan sensitivitas kontras pada frekuensi spasial sedang. ${ }^{49}$

Hasil penelitian ini berbeda dengan hasil yang di dapat pada penelitian Costa dan kawan-kawan (2012) yang menemukan penurunan sensitivitas kontras pada petugas yang terpapar dengan organic solvent dibandingkan dengan grup kontrol. Namun tidak terdapat hubungan yang bermakna antara lama bekerja dengan penurunan sensitivitas kontras tersebut. ${ }^{24}$

Beberapa faktor dapat mempengaruhi inhalasi organic solvent yaitu: konsentrasi substansi di udara, kelarutan substansi pada darah dan jaringan, respiratory rate, lama paparan dan kondisi saluran nafas. Inhalasi organic solvent akan langsung di absorpsi dan menyebabkan konsentrasi di darah meningkat. ${ }^{50,51}$

Salah satu sumber paparan organic solvent pada petugas operator SPBU adalah ketika melakukan pengisian bensin. Konsentrasi organic solvent pada breathing zone ketika melakukan pengisian bahan 
bakar adalah $3,2 \mathrm{mg} / \mathrm{m}^{3}$ atau $1 \mathrm{ppm}$. Nilai rata-rata paparan individu terhadap organic solvent selama shift bekerja adalah 0.15 $\mathrm{mg} / \mathrm{m}^{3}$ atau 0,046 ppm. Sehingga semakin lama petugas operator tersebut bekerja, maka semakin banyak paparan terhadap organic solvent. Konsentrasi organic solvent di lingkungan SPBU di kota Padang tidak pernah dilakukan pengukuran, sehingga pada penelitian ini tidak dapat diketahui nilai rata-rata paparan pada petugas operator SPBU selama bekerja. ${ }^{8,12}$

Subyek yang mengalami penurunan penglihatan warna dan sensitivitas kontras pada penelitian ini sudah bekerja selama lebih dari 13 tahun. Salah satunya adalah subyek nomor 40, jenis kelamin laki-laki yang berumur 48 tahun, lama bekerja 23 tahun, riwayat pekerjaan sebelumnya sebagai karyawan toko. Subyek tersebut memiliki tajam penglihatan normal (20/20), nilai CCI paling tinggi $(1,29)$ dan nilai $\log$ contrast sensitivity paling rendah $(1,35)$. Subyek nomor 31, seorang laki-laki berusia 38 tahun dengan lama kerja 18 tahun, tidak ada riwayat pekerjaan sebelumnya, tajam penglihatan normal (20/20), subyek ini juga memiliki nilai CCI yang tinggi yaitu 1,16 dan nilai log contrast sensitivity 1,50. Subyek nomor 45, seorang perempuan berusia 38 tahun yang sudah bekerja selama 18 tahun, subyek belum pernah bekerja sebelum menjadi petugas operator. Subyek tersebut memiliki tajam penglihatan normal (20/20), nilai CCI tinggi yaitu 1,18 dan nilai log contrast sensitivity yang menurun yaitu 1,50. Semua subyek yang mengalami peningkatan nilai CCI dan penurunan nilai log contrast sensitivity pada penelitian ini memiliki status nutrisi yang baik, tidak merokok dan tidak memiliki penyakit paru namun tidak pernah menggunakan masker selama bekerja sehingga paparan terhadap organic solvent dalam waktu yang lama tanpa menggunakan alat pelindung diri akan menyebabkan efek toksik pada retina. Semakin lama petugas tersebut bekerja, maka nilai CCI akan meningkat dan nilai log contrast sensitivity akan menurun sehingga subyek tersebut akan mengalami penurunan penglihatan warna dan sensitivitas kontras. Pada semua subyek dengan peningkatan nilai CCI dan penurunan nilai log contrast sensitivity belum menimbulkan gejala sehingga tajam penglihatan masih normal.

Subyek yang bekerja lebih dari 10 tahun yang tidak mengalami penurunan penglihatan warna dan sensitivitas kontras (CCI 1,00 dan log contrast sensitivity 1.65) pada penelitian ini adalah subyek nomor 32,33 dan 34. Subyek no 32 adalah seorang laki-laki dengan umur 43 tahun, riwayat pekerjaan sebelumnya karyawan perusahaan minyak goreng, sudah bekerja selama 14 tahun dan selalu menggunakan masker ketika bekerja. Subyek no 33 dan 34 yang berusia 29 tahun dan 28 tahun, laki-laki, keduanya sudah bekerja selama 11 tahun dan tidak memiliki riwayat pekerjaan sebelum bekerja sebagai petugas operator, subyek tersebut menggunakan masker ketika bekerja. Ketiga subyek ini memiliki status nutrisi yang baik, tidak merokok dan tidak memiliki penyakit paru, sehingga faktor-faktor yang dimiliki pasien tersebut dapat membantu untuk mencegah terjadinya toksisitas dari organic solvent. Masker memiliki efek proteksi terhadap inhalasi organic solvent. Ada beberapa faktor yang mempengaruhi efektivitas masker, yaitu : kesesuaian ukuran masker dengan wajah, efektivitas catridge dalam membuang agen kimia dari udara, kemampuan menyimpan, lama penggunaan dan motivasi pekerja. Faktor lain juga dapat mempengaruhi efektivitas adalah : ventilasi paru dan absorpsi kulit, konsentrasi organic solvent di udara dan dosis absorpsi, serta faktor lain seperti umur, jenis kelamin, berat badan, status nutrisi dan variabilitas metabolik. Pacitto dan kawan kawan (2019) menyatakan bahwa masker wajah efektif menyaring partikel yang berukuran di bawah 2,5 $\mu \mathrm{m}$ (PM 2,5) dengan presentase $48 \%{ }^{37,40}$

Efek paparan organic solvent pada mata di pengaruhi oleh konsentrasi, durasi paparan, rute paparan dan beberapa faktor 
yang ada pada masing-masing individu seperti umur, jenis kelamin dan status nutrisi. Faktor yang juga sangat penting adalah pergerakan organic solvent melewati barriers pada mata. Sel endotel kapiler pembuluh darah retina memiliki tight junctions dan kapiler ini akan membentuk blood retinal barrier yang tidak dapat di tembus oleh komponen kimia pada kondisi normal, namun pada level papil nervus optikus tidak memiliki kapiler tersebut sehingga molekul hidrofilik dapat memasuki papil nervus optikus melalui difusi dan dapat menyebabkan kerusakan selektif pada bagian ini. ${ }^{52,53,40}$

Korelasi antara nilai CCI dengan nilai $\log$ contrast sensitivity menunjukkan korelasi negatif, dimana peningkatan nilai CCI berhubungan dengan penurunan nilai $\log$ contrast sensitivity pada petugas operator SPBU. Paparan organic solvent menyebabkan apoptosis dari sel fotoreseptor, terjadi gangguan hantaran ke sel parvo dan magno, sehingga terjadi penurunan penglihatan warna dan sensitivitas kontras. Penurunan penglihatan warna ditandai dengan peningkatan nilai CCI, sedangkan penurunan sensitivitas kontras di tandai dengan penurunan nilai $\log$ contrast sensitivity. ${ }^{52,53}$

\section{SIMPULAN}

\section{Simpulan}

1. Pada pemeriksaan penglihatan warna dan sensitivitas kontras yang dilakukan pada petugas operator SPBU di kota Padang yang bekerja 1- 5 tahun dan 510 tahun tidak ditemukan penurunan penglihatan warna dan sensitivitas kontras. Penurunan penglihatan warna dan sensitivitas kontras ditemukan pada petugas yang sudah bekerja lebih dari 10 tahun sebanyak 12 subyek $(80 \%)$.

2. Terdapat hubungan yang bermakna secara statistik antara lama bekerja terhadap penurunan penglihatan warna pada petugas operator SPBU di kota Padang dengan nilai $\mathrm{P}=0,000$.

3. Terdapat hubungan yang bermakna secara statistik antara lama bekerja terhadap penurunan sensitivitas kontras pada petugas operator SPBU di kota

Padang dengan nilai $\mathrm{P}=0,000$.

\section{UCAPAN TERIMAKASIH}

Terima kasih kepada SPBU kota Padang, PT Pertamina Persero Marketing Branch Manager Sumbar-Riau dan Bagian Ilmu Kesehatan Mata Fakultas Kedokteran Universitas Andalas/ RSUP DR.M.Djamil Padang.

\section{REFERENSI}

1. Firetone JA, Gospe SM. Organic solvents.in:Clinical

Neurotoxicology. 2009.pp.402-412.

2. Oliveira AR, Neto AC, Andrade $\mathrm{MJO}$, et al. Organic solvent exposure and contrast sensitivity comparing men and women. 2018;51(3):pp.1-8

3. Gong Y, Kishi R, Kasai S, et al. Visual Dysfunction in Workers Exposed to a Mixture of Organic Solvents.2003:pp.703-710.

4. Vienna MK. Overview of the Neurotoxic effects in solvent exposed workers. 2002:pp.217-232.

5. Pranjic N, Mujagic H, Nurkic M, et al. Assassment of Health Effects in Workers at Gasoline Station.Bosnian Journal of Basic Medical Sciencess.2002:pp.35-45.

6. Alsaggaf S. Impact of Gasoline on Health An Update Review on Gasoline Induced Histopathological Effect in Laboratory Animals.2018;6(2): pp.33-41.

7. Ekpenyong CE, Asuquo E A.Recent Advances in Occupational And Environmental Health Hazards of Workers Exposed to Gasoline Compounds.2017;30(1):pp.1-26

8. Theakston F. Benzene.In: Air Quality Guidelines for Europe Second Edition. WHO Regional publication. Denmark.2000.pp.1-18 
9. Hayat I. Analisis besaran risiko kesehatan paparan benzene pada petugas operator SPBU di wilayah Ciputat tahun 2012. Universitas Islam Negeri Syarif Hidayatullah Jakarta : 2013.pp.1-88.

10. Drew D, Harkins DK, Connor RO, et al. Case Studies in Environmental Medicine. Atlanta, Georgia: ATDRS; 2000.pp. 1-25

11. Kementerian tenaga kerja dan transmigrasi Republik Indonesia. Peraturan menteri tenaga kerja dan transmigrasi nomor PER.13/MEN/X/2011 tahun 2011 tentang nilai ambang batas faktor fisika dan faktor kimia di tempat kerja . Indonesia; 2011.

12. Bayliss D, Jinot J, Sonawane B. Toxicological review of benzena; no cancer effects. 2002.pp:1-146.

13. Caprino L, Togna G. Potential health effects of gasoline and its constituents; a review of current literature (1990-1997) on toxicological data. 1998; 106(3):pp.115-125.

14. Aksoy M, Dincol K, Erdem S, et al. Details of Blood Changes In 32 Patients with Pancytopenia Associated with Long Term Exposure to benzena.1972;29:pp.5664.

15. El shakour AA, El ebiarie AS, Ibrahim $\mathrm{YH}$, et al. Effect of benzena on oxidative stress and the functions of liver and kidney in rats. Journal environment occupational science.2015; 4(1):pp. 34-39

16. Susilaningtyas M, Suwondo A, Ekawati. Hubungan Paparan Benzene Dengan Fungsi Paru pada Awak Mobil Tangki BBM di PT X Semarang. 2018;6(5):pp.579-586.
17. Dase T, Russeng S, Muis M. Faktor yang Berhubungan dengan Kapasitas Paru pada Karyawan SPBU Pasti Pas di Kecamatan Tamalanrea Kota Makasar Tahun 2013. 2013:pp.1-8.

18. Witter RZ, Tenney L, Clark S, et al. Occupational exposures in oil and gas extraction industry:state of the science and research recommendations. $2014 ; \quad$ 57(7): pp.847-856.

19. Simunovic MP. Acquired color vision deficiency. Survey of ophthalmology. 2016:pp.132-155.

20. Paramei GV. Color perception and environmentally based impairments. 2013:pp.1-6.

21. Lee EH, Eum KD, Cho SI, et al. Acquired dyschromatopsia among petrochemical industry workers exposed to benzena. 2007:pp. 356363.

22. Bockelmann I, Pfister EA, Peters B. Influence of chronic exposure to organic solvent mixtures on contrast sensitivity in silk screen printers:matched pair analysis. 2005:pp. 505-510.

23. Semple S, Dick F, Osborne S, et al. Impairment of colour vision in workers exposed to organic solvents.2000: pp.582-587.

24. Costa TL, Barboni MT, Moura AL, et al. Longterm occupational exposure to organic solvents affect color vision, contrast sensitivity and visual fields. 2012;7(8):pp.1-8.

25. Ramirez C, Pham K, Franco MF. Hydroquinone induces oxidative and mitochondrial damage to human retinal muller cells (MIO-M1). 2013:pp.102-108.

26. Hiraku Y, Kawanishi S. Oxidative DNA Damage and Apoptosis 
Induced by Benzene Metabolites. 1996;56:pp.5172-5178.

27. Carelli V, Cisneros FN, Sadun AA. Mitochondrial Dysfunction as a Cause of Optic Neuropathies. 2004;4:pp.53-89

28. Maher P, Hanneken A. The Molecular Basis Of Oxidative Stress Induced Cell Death In An Immortalized Retinal Ganglion Cell Line.2005;46(2):pp.749-757

29. Heidmann DG, Suner IJ, Catanuto P, et al. Cigarrette Smoke Related Oxidants and Development of Sub RPE Deposits In An Experimental Animal Model of Dry AMD. 2006;47(2):pp.729-737.

30. Cantor BL, Rapuano CJ, Cioffi GA. Retinal physiology and psychophysics. In :Retina and Vitreous. American Academy of Ophthalmology. San Fransisco. 2018-2019.pp.56-60.

31. Skuta GL, Cantor BL, Ciofi GA. The patient with decreased vision; evaluation. In: Neuroophthalmology, Section 5. American Academy Of Ophthalmology. San Francisco.2013-2014. pp 84-85

32. Paramei GV, Baron MM, Seeber A. Impairment of colour vision induced by organic solvents: A meta analysis study. 2004;24:pp.803-816.

33. Kaur S, Mursyid A, Kamarudin A,et al. Effect of petroleum derivatives and solvents on colour perception. 2004;87:pp.339-343.

34. Richman J, Spaeth GL, Wirostko B. Contrast sensitivity basics and critique of currently available test. Journal cataract and refractive surgery. 2013:pp.1-7.

35. Rubin GS. Visual acuity and contrast sensitivity.In: Ryan SJ,
ed.Retina. Los Angeles-USA: Elsevier-Saunders:2006:pp.127-131.

36. Pelli DG, Robson JG, Wilkins AJ. The design of a new letter chart for measuring contrast sensitivity. Clinical vision science. 1988;2:pp.187-199.

37. Pacitto A, Amato F, Salmatodinis A, et al. Effectiveness of commercial face masks to reduce personal PM exposure. Science of the total environment.2019:pp.1582-1590

38. Salim RN. Analisis Risiko Kesehatan Pajanan Benzena pada Karyawan di SPBU X Pancoranmas Depok.2011:pp.60-80.

39. Mahendra AD. Analisis Pengaruh Pendidikan, Upah, Jenis kelamin, Usia dan Pengalaman Kerja terhadap Produktivitas Tenaga Kerja. Universitas Diponegoro Semarang : 2014.pp.43-45.

40. Gobba F, Ghittori S, Imbriani M, et al. Evaluation of Half Mask Respirator Protection in Styrene Exposed Workers. International Arch Occupational Environment Health ;73:pp. 56-60.

41. Potts AM, Praglin J, Farkas I, et al. Studies on the Visual Toxicity of Methanol. 1995: pp 76-82.

42. Good GW, Schepler A, Nichols JJ, et al. The Reliability of the Lanthony Desaturated D15 Test.2005;82(12):pp.1054-1059.

43. Karatepe AS, Kose S, Egrilmez S. Factors Affecting Contrast Sensitivity in Healthy Individuals a Pilot Study. 2017;47:pp.80-84.

44. Lacerda EM, Lima MG, Rodrigues AR, et al. Psychophysical Evaluation of Achromatic and Chromatic Vision of Workers Chronically Exposed to Organic Solvents. 2012.pp. 1-7. 
45. Beckman S, Eisen EA, Bates MN, et al. Acquired Color Vision Defects and Hexane Exposure a Study of San Francisco Bay Area Automotive Mechanics. 2016; 183(11):pp. 969976.

46. Ihrig A. Pilot Study on Prevalence of Color Vision Dysfunction in Long Term Solvent Exposed Painters. 2003;41(1):pp 39-42

47. Allam HK, Soliman S, Wasfy T, et al. The Neuro Ophthalmological Effects Related to Longterm Occupational Exposure to Organic Solvents in Painters. 2017: pp. 1-8

48. Indhushree R, Monica R, Coral K, et al. Visual Functions of Workers Exposed to Organic Solvents in Petrochemical Industries. 2016;20:pp.133-137.

49. Fiedler N, Weisel C, Nwankwo C, et al. Chronic Exposure to Solvent 54.
Among Construction Painters. 2018;60(12):pp. 663-670.

50. Mergier D, Blain L. Assessing color vision loss among solvent exposed workers. 1987:pp.195-203.

51. Dahlstrom DL, Buckalew M. Solvents and Industrial Hygiene. In:Principles and Methods of Toxicology Fifth Edition. USA.2005.pp.693-721.

52. Cantor BL, Rapuano CJ, Cioffi GA. Basic anatomy. In :Retina and Vitreous. American Academy of Ophthalmology. San Fransisco. 2018-2019.pp.14-26.

53. Fox DA, Boyes WK. Toxic Responses of The Ocular and Visual System. In Toxicology The Basic Science of Poisons. USA;2001:pp. 565-587. 